\title{
MODEL SEBARAN SEDIMEN SUSPENSIMUARA SUNGAI SIAK RIAU
}

\section{Yeeri Badrun dan Amin Ridhoni}

\author{
Fakultas MIPA dan Kesehatan Universitas Muhammadiyah Riau \\ Email: yeeri.badrun@gmail.com
}

\begin{abstract}
ABSTRAK
Simulasi hidrodinamika aliran dan sedimen menggunakan modul yang terdapat dalam perangkat lunak MIKE21, yaitu Hydrodinamika Modul dan Mud Transport Modul. Model hidrodinamika tersebut merupakan model dengan metode elemen hingga dua dimensi horisontal dan rerata kedalaman. Dengan model numeris ini dapat diprediksi pola aliran, elevasi muka air dan komponen kecepatan horisontal baik pada kondisi aliran permanen (steady flow) maupun aliran tak permanen (unsteady flow) serta sedimentasi. Di dalam simulasi sebaran sedimen di muara Sungai Siak, dilakukan dalam 3 skenario input konsentrasi yaitu: skenario 1 dengan input konsentrasi $0,1 \mathrm{~kg} / \mathrm{m}^{3}$, skenario 2 dengan input konsentrasi 0,5 $\mathrm{kg} / \mathrm{m}^{3}$ dan skenario 3 dengan input konsentrasi $1 \mathrm{~kg} / \mathrm{m}^{3}$. Hasil simulasi pola arus disajikan dalam bentuk vektor dan kontur kecepatan serta dalam bentuk grafik. Secara visual kecepatan yang terjadi akibat terjadinya pasang surut adalah pada saat surut kecepatannya berkisar antara $0,20 \mathrm{~m} /$ detik sampai 0,34 $\mathrm{m} /$ detik dan saat pasang berkisar antara $0,01 \mathrm{~m} /$ detik sampai $0,02 \mathrm{~m} /$ detik. Pada saat pasang sebaran sedimen suspensi akan mengarah ke selatan dan pada saat surut sebaran sedimen suspensi cenderung ke arah utara. Perubahan elevasi dasar sungai akan meningkat secara signifikan dengan bertambahnya konsentrasi sedimen. Perubahan sangat terlihat jelas dari input konsentrasi $0,5 \mathrm{~kg} / \mathrm{m}^{3} \mathrm{ke} 1 \mathrm{~kg} / \mathrm{m}^{3}$ yaitu dari $0,036 \mathrm{~cm} /$ tahun menjadi $0,9 \mathrm{~cm} /$ tahun. Sedangkan pada dasar laut belum mengalami perubahan elevasi dasar karena konsentrasi sedimen terdifusi secara merata ke segala penjuru.
\end{abstract}

Kata Kunci: sedimen, suspensi, hidrodinamika, elevasi, pemodelan numerik

\section{PENDAHULUAN}

Pesatnya perkembangan wilayah pesisir timur Sumatera terutama di muara Sungai Siak dalam hal pengembangan kegiatan industri, pemukiman penduduk, jalur pelayaran dan perhubungan, pelabuhan, pertanian, perikanan serta reklamasi pantai telah memberikan dampak terhadap ekosistem pesisir.

Jika hal ini berlangsung secara terus menerus maka proses pendangkalan akibat proses sedimentasi akan berdampak terhadap berbagai aspek dalam perairan baik dari segi aspek biologis maupun ekologis.

Proses sedimentasiterkait hubungannya dengan sedimen terakumulasi, sedimen tersuspensi dan karakteristik fraksi sedimen, penggolongan dalam parameter statistik sedimen dan sebaran sedimen dapat menggambarkan kondisi lingkungan perairan dari beberapa faktor oseanografi yang mempengaruhi proses sedimentasi di sekitarnya. Untuk mengetahui proses sedimentasi dapat dilakukan dengan kajian-kajian hidrodinamika.
Kajian hidrodinamika kondisi sekarang (kondisi eksisting) adalah kajian yang berdasar pada data-data yang ada pada saat atau pada saat pengukuran di lapangan. Sedangkan yang dimaksud kondisi yang akan datang (kondisi alternatif) adalah kondisi dimana adanya perubahan kondisi eksisting dimasa datang. Metode yang biasa digunakan untuk mengkaji kejadian masa sekarang dan masa yang akan datang adalah dengan membuat model matematik.

Model matematik adalah tiruan kondisi fisik lapangan yang diterjemahkan dalam persamaan matematik dengan memegang kaidah-kaidah atau hukum alam yang berlaku. Model matematik dikerjakan dengan perangkat lunak dan bahasa pemrograman dan biasanya yang sudah dikemas dalam bentuk software.

Secara spesifik penelitian ini dilakukan bertujuan untuk melakukan dan menganalisis simulasi pola sebaran sedimen dan simulasi perubahan laju elevasi dasar perairan dengan menggunakan model matematik 2 dimensi. 
Luaran dari simulasi ini adalah mengetahui model hidrodinamika dari sedimen tersuspensi di perairan sungai dan muara sungai Siak sehinga dapat menghasilkan:

1. Rancangan model komputasi yang dapat dipergunakan untuk menganlisis pola transpor sedimen di perairan sungai.

2. Perkiraan kecepatan pendangkalan perairan sungai akibat erosi dan sedimentasi.

3. Sebagai salah satu bahan untuk mengkaji model transportasi pada tingkat yang lebih lanjut termasuk di muara sungai dan pesisir pantai.

\section{METODOLOGI PENELITIAN}

\section{Daerah Studi}

Secara administrasi Muara Sungai Siak berada di wilayah Kabupaten Siak Propinsi Riau. Secara geografis berada pada koordinat $1^{\circ} 11^{\prime} 18.24^{\prime \prime}$ LU $-1^{\circ} 15^{\prime} 17.29 "$ LU dan $102^{\circ}$ $8^{\prime} 8.77 " \mathrm{BT}-102^{\circ} 11^{\prime} 16.12^{\prime \prime} \mathrm{BT}$, dengan topografi realtif datar, kemiringan sekitar $3 \%$ dan ketinggian dari permukaan laut sekitar 1-2 m. Kedalaman perairan muara Sungai Siak berkisar antara 5-10 m. Pergerakan air di muara Sungai Siak sangat di pengaruhi oleh pola pasang surut dan aliran air dari arah hulu. Pola pasang surut di muara sungai ini bertipe semi diurnal yaitu dalam sehari terjadi dua kali pasang dan dua kali surut yang hampir sama tingginya. Debit air Sungai Siak berkisar antara $45 \mathrm{~m}^{3} / \mathrm{dtk}-1.700 \mathrm{~m}^{3} / \mathrm{dtk}$ dengan debit rata-rata $200-300 \mathrm{~m}^{3} / \mathrm{dtk}$.

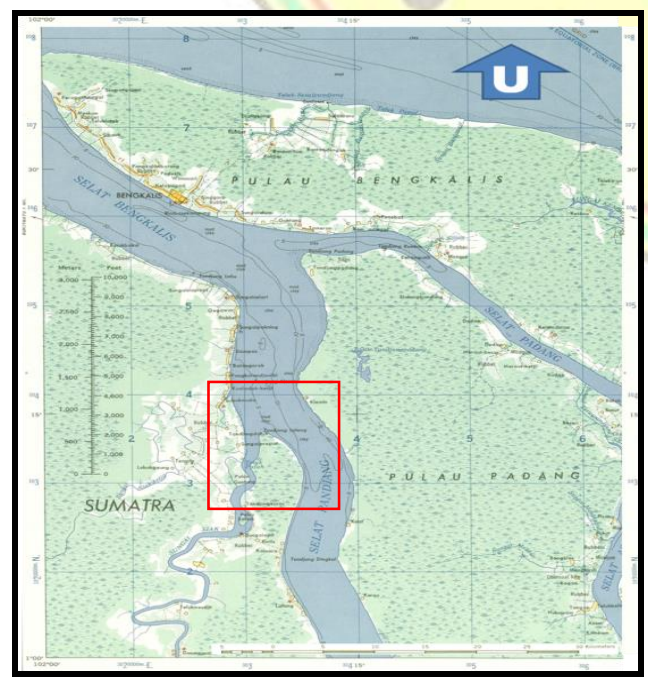

Gambar 1. Lokasi Studi

\section{Desain Model}

Daerah model meliputi wilayah perairan selat bengkalis, Muara Suangai Siak, Selat Padang dan Selat Panjang dengan batas-batas lintang dan bujur sebagai berikut:

$\begin{array}{lll}\text { Batas utara : } 1^{0} 30^{\prime} 0^{\prime}, \quad \mathrm{LU} & \\ \text { Batas selatan } & : 1^{0} 0^{\prime} 0^{\prime \prime} & \mathrm{LU} \\ \text { Batas barat } \quad: 102^{\circ} 00^{\prime}, & \mathrm{BT} \\ \text { Batas timur : } 102^{0} 30^{\prime} 0^{\prime}, \quad \text { BT } & \end{array}$

\section{Skenario Model}

Model Hidrodinamika dan disperse sedimen disimulasikan dengan memasukkan data psang surut, angin dan debit air di Sungai Siak. Simulasi dilakukan dalam berbagai skenario inputan konsentrasi sedimen dari Sungai Siak. Dalam simulasi model sebaran sedimen suspensi ini dilakukan 3 (tiga) skenario model yaitu:

- $\quad$ skenario 1 dengan input konsentrasi 0,1 $\mathrm{kg} / \mathrm{m} 3$,

- $\quad$ skenario 2 dengan input konsentrasi 0,5 $\mathrm{kg} / \mathrm{m} 3$

- $\quad$ skenario 3 dengan input konsentrasi 1 $\mathrm{kg} / \mathrm{m} 3$

Lokasi input konsentrasi sedimen berkisar $1500 \mathrm{~m}$ dari muara Sungai Siak. Material sedimen suspensi berupa fine silt dengan kecepatan endap berkisar $0,009 \mathrm{~cm} /$ detik dengan ukuran butir $10 \mu \mathrm{m}$.

\section{Tahapan Simulasi Model Hidrodinamika}

Model hidrodinamika dijalankan untuk mensimulasi arus yang dibangkitkan oleh aliran air dari Sungai Siak. Debit air Sungai Siak mempengaruhi sirkulasi arus dekat muara sungai. Arus di Selat Bengkalis, Selat Padang dan Selat Panjang dipengaruhi pula oleh pasang surut dan angina yang bertiup diatasnya.

Gerak sirkulasi arus di perairan dangkal diasumsikan sebagai aliran masa air yang bercampur sempurna (homogeny) mulasi dari permukaan sampai dasar perairan dan pengaruh angin dipermukaan diasumsikan mencapai dasar laut. Oleh karena itu persamaan model yang dipakai adalah persamaan yang diintegrasikan terhadap kedalaman. Dalam model ini air laut dianggap sebagai fluida yang tak mampu mampat (incompressible fluida). 


\section{Rancangan Model Matematik}

Simulasi hidrodinamika aliran dan sedimen polutan menggunakan modul yang terdapat pada perangkat lunak MIKE 21, yaitu Hydrodynamic Module dan Sand Transport (ST). Model hidrodinamika tersebut merupakan model dengan metode elemen hingga dua dimensi horisontal dengan rerata kedalaman. Dengan model numeris ini dapat diprediksi pola aliran, elevasi muka air dan komponen kecepatan horisontal, baik pada kondisi aliran permanen (steady flow) maupun aliran tak permanen (unsteady flow) serta sedimentasi.

Untuk melakukan simulasi sedimen maka diperlukan simulasi hidrodinamik arus terlebih dahulu. Hasil simulasi arus digunakan sebagai input untuk simulasi sedimen. Skema simulasi dapat disajikan dalam bagan alir seperti ditunjukan pada gambar di bawah ini.

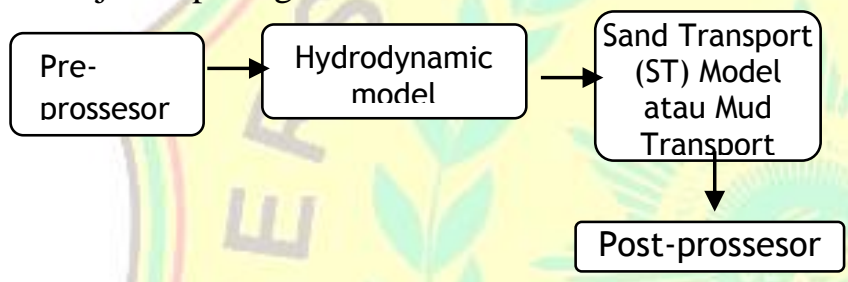

\section{Gambar 2. Skematik simulasi secara keseluruhan}

\section{a. Persamaan Dasar Hydrodinamika}

Model matematik yang digunakan untuk prodiksi hidrodinamika aliran didasarkan pada 2 persamaan dasar, yaitu persamaan konservasi massa (persamaan kontinuitas) dan persamaan momentum, sebagai berikut:

Persamaan kontinuitas:

$$
\frac{\partial h}{\partial t}+\frac{\partial h \bar{u}}{\partial x}+\frac{\partial h \bar{v}}{\partial y}=h S
$$

Persamaan Momentum:

Persamaan momentum untuk aliran dua dimensi pada arah $\mathrm{x}$ dan y dapat ditulis dalam bentuk persamaan berikut ini:

$\frac{\partial u}{\partial t}+u \frac{\partial u}{\partial x}+v \frac{\partial u}{\partial y}+g\left(\frac{\partial h}{\partial x}+\frac{\partial a_{0}}{\partial x}\right)-\frac{\varepsilon_{x x}}{\rho} \frac{\partial^{2} u}{\partial x^{2}}-\frac{\varepsilon_{x y}}{\rho} \frac{\partial^{2} u}{\partial y^{2}}+\frac{g u}{C^{2} h} \sqrt{u^{2}+v^{2}}=0$

$\frac{\partial v}{\partial t}+u \frac{\partial v}{\partial x}+v \frac{\partial v}{\partial y}+g\left(\frac{\partial h}{\partial y}+\frac{\partial a_{0}}{\partial y}\right)-\frac{\varepsilon_{x x}}{\rho} \frac{\partial^{2} v}{\partial x^{2}}-\frac{\varepsilon_{y v}}{\rho} \frac{\partial^{2} v}{\partial y^{2}}+\frac{g v}{C^{2} h} \sqrt{u^{2}+v^{2}}=0$.

dengan: $\mathrm{u}=$ kecepatan horisontal aliran arah- $\mathrm{x} \quad \mathrm{v}=$ kecepatan horisontal arah-y,

$\mathrm{t}=$ fungsi waktu ,

$\mathrm{g}=$ percepatan gravitasi ,

$\mathrm{h}=$ kedalaman air,

$\mathrm{a} 0=$ elevasi dari dasar tampang,

$\rho=$ massa jenis,

$\varepsilon \mathrm{xx}=$ koef.pertukaran turbulensi normal arahx

$\varepsilon x y=$ koefpertukaranturbulensi tangensial arah- $x$,

$\varepsilon y x=$ koef.pertukaran turbulensi tangensial arah-y,

$\varepsilon y y=$ koef. pertukaran turbulensi normal arah-y

$\mathrm{C}=$ koef. kekasaran Chezy (atau koef. Manning,

$$
\mathrm{n}=1 / \mathrm{Ch} 1 / 6 \text { ) }
$$

\section{b. Persamaan Dasar Sand Transport (ST)}

Formula dari model adalah system dua dimensi dengan kedalaman rerata yang mana konsentrasi arah vertikal diasumsikan seragam. Modul Sand Transport (ST) merupakan aplikasi pada angkutan sedimen dengan material dasar lempung atau pasir. Sand Transport (ST) modul ini dikhususkan untuk pemodelan non-cohesive sedangkan untuk material cohesive menggunakan modul mud transport (MT). Persamaan dasar pada Mud Transport (MT) di ekspresikan dalam persamaan transport dua dimensi didasarkan pada persamaan konveksi-difusi sedimen suspensi yaitu:

$\frac{\partial C}{\partial t}+\bar{U} \frac{\partial C}{\partial x} \ddot{+} \bar{V} \frac{\partial C}{\partial y}=\frac{\partial}{\partial x}\left(D x \frac{\partial C}{\partial x}\right)+\frac{\partial}{\partial y}\left(D y \frac{\partial C}{\partial y}\right)+\alpha_{1} C+\alpha_{2}$ dengan:

C = konsentrasi,

$\bar{U} \quad=$ kecepatan rata-rata aliran arah

$\mathrm{X}$,

$\bar{V} \quad=$ kecepatan rata-rata aliran arah $\mathrm{y}$,

Dx $=$ koefisien difusi efektif $\operatorname{arah} \mathrm{x}$,

Dy $=$ koefisien difusi efektif arah $\mathrm{y}$,

$\alpha_{1}, \alpha_{2}=$ koefisien source term

Pada persamaan di atas, koefisien difusiturbulen searah arah aliran padat dirumuskan sebagai berikut (persamaan. Elder),

$\mathrm{Dx}=5.93 \mathrm{HU}^{*} \ldots \ldots . .1-\ldots \ldots \ldots . .5-$

Sedangkan koefisien- difusi turbulen arah tegak lurus arah aliran adalah,

Dy $=0.23 \mathrm{H} \mathrm{U}^{*} \ldots \ldots \ldots \ldots \ldots \ldots . . .4-$ 
dengan kecepatan geser dihitung dengan rumus:

$$
\begin{aligned}
& U^{*}=\frac{\sqrt{g} \bar{U} n}{H^{1 / 6}} \ldots \ldots \ldots \ldots \ldots \ldots-5- \\
& \begin{array}{lll}
\operatorname{dimana} & \mathrm{H} & =\text { kedalaman aliran } \\
& \mathrm{U}^{*} & =\text { kecepatan geser }
\end{array}
\end{aligned}
$$

Tabel 1. Kecepatan pengendapan beberapa material sedimen suspense

\begin{tabular}{|c|c|c|c|c|c|c|}
\hline Diameter & \multicolumn{7}{|c|}{ Settling Velocity in Centimeters per Second } & \\
\hline (..MI) & $0^{\circ} \mathrm{C}$ & $5^{\circ} \mathrm{C}$ & $10^{\circ} \mathrm{C}$ & $15^{\circ} \mathrm{C}$ & $20^{\circ} \mathrm{C}$ & Particle \\
\hline 0.01 & 0.005 & 0.006 & 0.007 & 0.008 & 0.009 & Fine Silt \\
\hline 0.02 & 0.020 & 0.023 & 0.027 & 0.031 & 0.035 & Median Silt \\
\hline 0.03 & 0.044 & 0.052 & 0.060 & 0.069 & 0.078 & \\
\hline 0.04 & 0.078 & 0.092 & 0.107 & 0.122 & 0.139 & Coarse Silt \\
\hline 0.05 & 0.122 & 0.143 & 0.167 & 0.191 & 0.217 & \\
\hline 0.06 & 0.176 & 0.207 & 0.240 & 0.275 & 0.313 & \\
\hline 0.07 & 0.239 & 0.281 & 0.327 & 0.375 & 0.426 & Very Fine Sand \\
\hline 0.08 & 0.312 & 0.367 & 0.427 & 0.490 & 0.556 & \\
\hline 0.09 & 0.395 & 0.465 & 0.540 & 0.620 & 0.704 & \\
\hline 0.110 & 0.488 & 0.574 & 0.667 & 0.765 & 0.869 & \\
\hline 0.11 & 0.590 & 0.694 & 0.807 & 0.926 & 1.051 & \\
\hline 0.12 & 0.703 & 0.826 & 0.960 & 1.101 & 1.251 & \\
\hline 0.13 & 0.825 & 0.970 & 1.127 & 1.293 & 1.468 & Fine Sand \\
\hline 0.14 & 0.956 & 1.125 & 1.307 & 1.499 & 1.703 & \\
\hline 0.15 & 1.098 & 1.291 & 1.501 & 1.721 & 1.955 & \\
\hline 0.16 & 1.249 & 1.469 & 1.707 & 1.958 & 2.224 & \\
\hline 0.17 & 1.410 & 1.658 & 1.928 & 2.211 & 2.511 & \\
\hline 0.18 & 1.581 & 1.859 & 2.161 & 2.478 & 2.815 & \\
\hline 0.19 & 1.761 & 2.072 & 2.408 & 2.761 & 3.136 & \\
\hline 0.20 & 1.952 & 2.295 & 2.668 & 3.060 & 3.475 & \\
\hline${ }^{\circ} \mathrm{F}$ & 32 & 41 & 50 & 59 & 68 & \\
\hline & & & & & & Source Fifield, 2001 \\
\hline
\end{tabular}

\section{HASIL DAN PEMBAHASAN}

Data primer untuk simulasi diperoleh dengan melakukan pengukuran langsung dilapangan meliputi: pengukuran pasang surut dan kecepatan arus. Grid yang digunakan adalah triangular grid. Pembuatan grid menggunakan perangkat lunak MIKE 21.

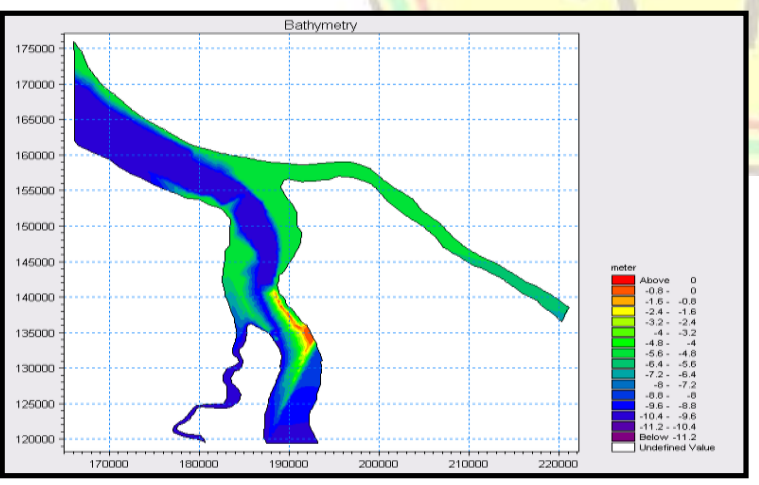

Gambar 3. Simulasi Kedalaman Muara Sungai Siak

\section{Pola Arus}

Pola arus yang diamati untuk kondisi pasang tertinggi dan kondisi surut terendah. Hasil simulasi pola arus disajikan dalam bentuk vector dan kontur kecepatan yang terjadi. Hasil pola arus kondisi eksisting pada saat pasang disajikan pada Gambar 5, sedangkan pada saat surut disajikan pada Gambar 6. Secara visual kecepatan yang terjadinya pasang surut dapat dilihat dari grafik pengamatan di Statiun Sei Pakning pada Grafik 1 adalah sebagai berikut:

a. Saat surut berkisar antara $0,20 \mathrm{~m} /$ detik sampai $0,34 \mathrm{~m} /$ detik.

b. Saat pasang berkisar antara $0,01 \mathrm{~m} /$ detik sampai $0,02 \mathrm{~m} /$ detik

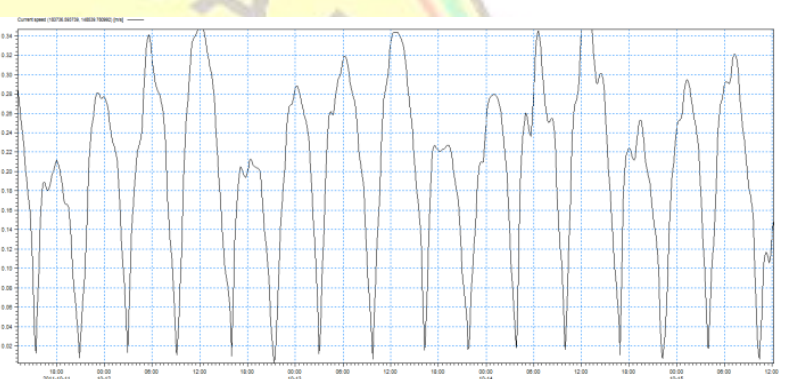

Grafik 1. Kecepatan arus hasil simulasi pada stasiun Sei Pakning

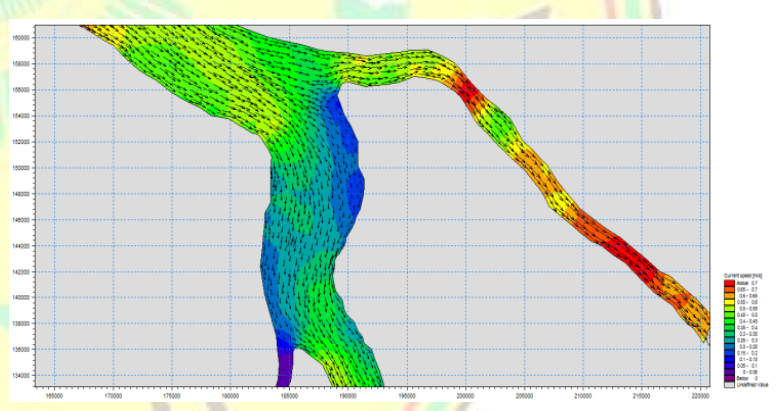

Gambar 5. Pola arus pada saat pasang di Selat Bengkalis

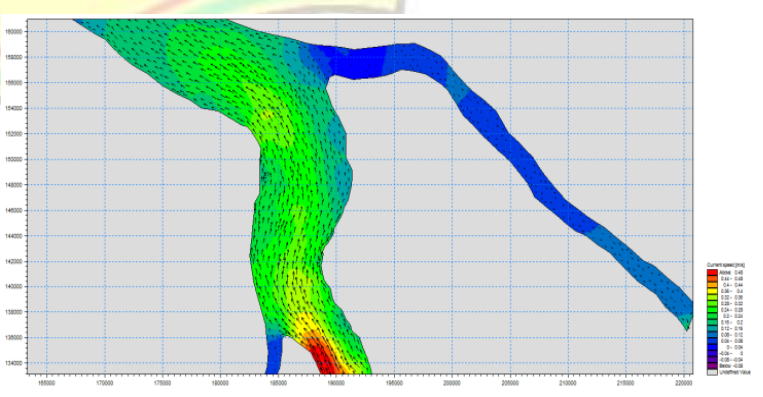

Gambar 6. Pola arus pada saat surut di Selat Bengkalis 
Pola Sebaran Sedimen di Selat Bengkalis.

Hasil pola arus yang terjadi pada saat pasang dan pada saat surut akan memberikan pola sebaran sedimen suspense yang terjadi di muara Sungai Siak. Pada saat pasang sebaran sedimen akan mengarah atau cenderung menyebar ke arah selatan sedangkan pada saat surut sebaran sedimen tersuspense akan mengarah ke arah utara.

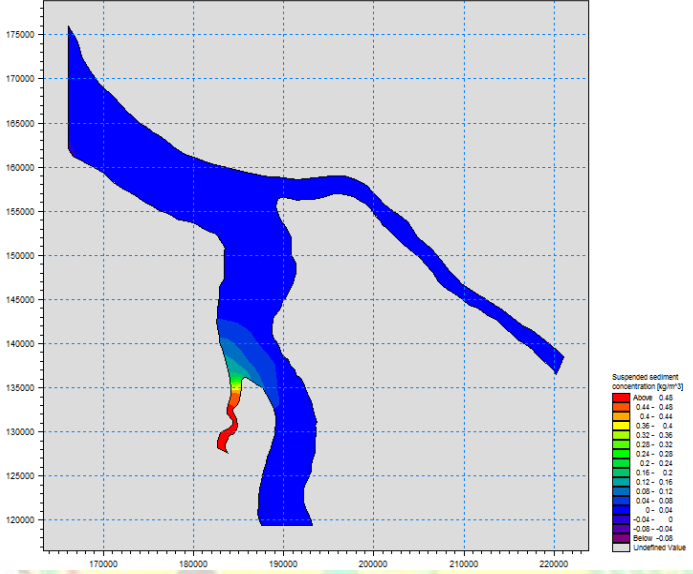

Gambar 7. Pola arah sebaran sedimen pada

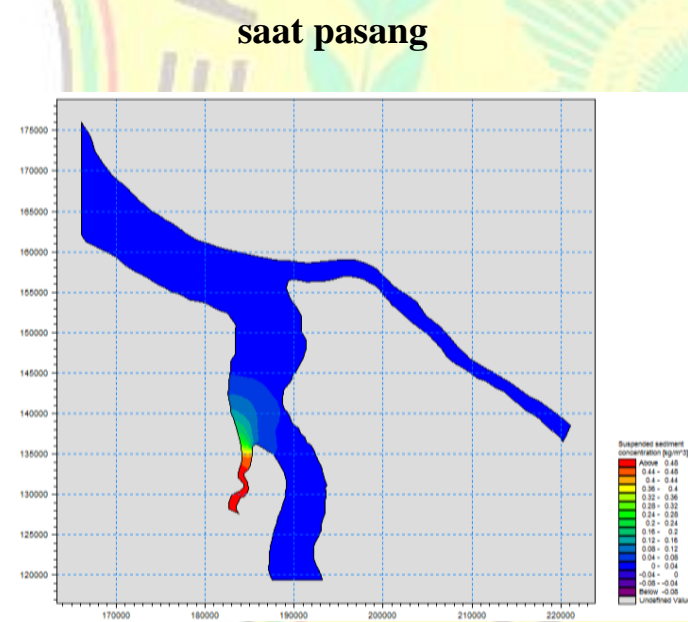

Gambar 8. Pola arah sebaran sedimen pada saat surut.

Untuk dapat melihat perubahan elevasi dasar secara seri waktu selama simulasi maka dilakukan eksplorasi data hasil simulasi dengan cara menempatkan titik pengamatan pada titik tertentu. Pada kajian ini titik pengamatan ditempatkan seperti disajikan pada gambar berikut ini:

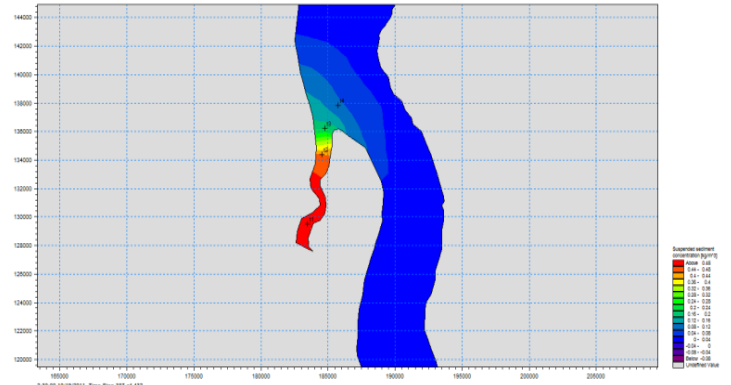

Gambar 9. Penempatan titik-titik pengamatan

\section{Konsentrasi Sebaran Sedimen.}

Konsentrasi sedimen yang terjadi pada tiap titik akan selalu berfluktuasi walaupun kecil. Hal ini disebabkan oleh proses sebaran sedimen yang dipengaruhi oleh kecepatan aliran yang terjadi. Sedangkan kecepatan itu sendiri di area yang dikaji sangat berfluktuasi disebabkan oleh pasang surut air laut. Sebaran konsentrasi sedimen untuk input sedimen $0,1 \mathrm{~kg} / \mathrm{m}^{3}, 0,5 \mathrm{~kg} / \mathrm{m}^{3}$ dan $1 \mathrm{~kg} / \mathrm{m}^{3}$ berurutan disajikan pada Gambar 10 sampai dengan Gambar 12.
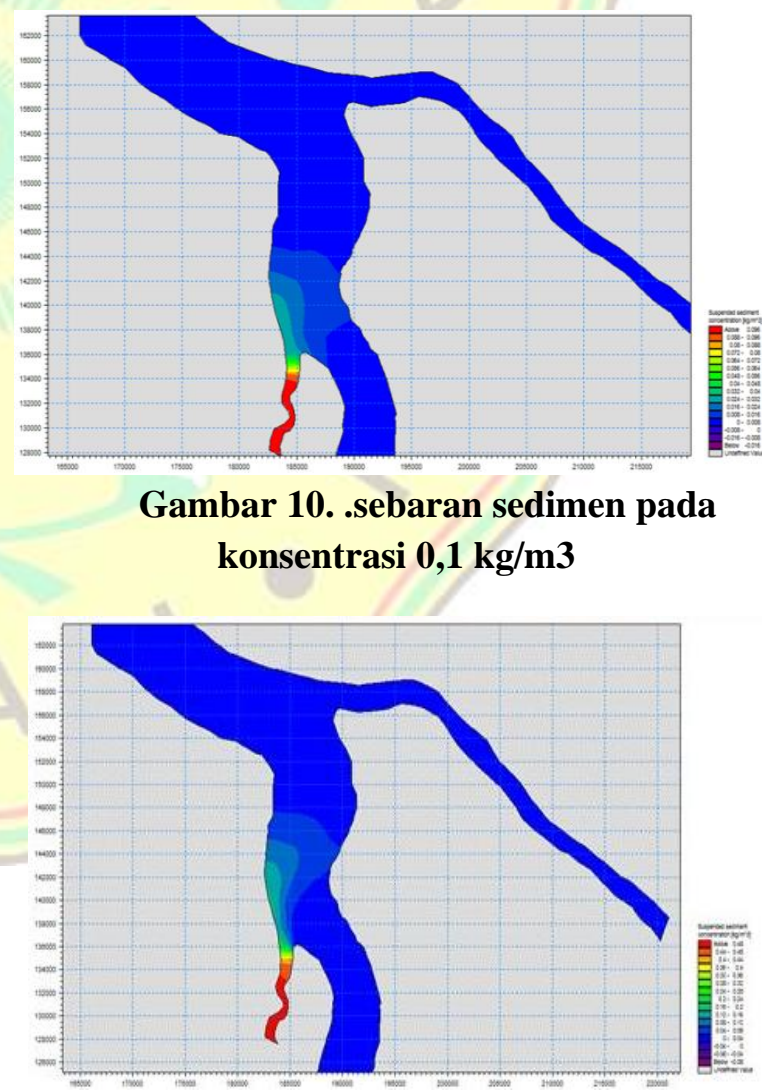

Gambar 11. sebaran sedimen pada konsentrasi $0,5 \mathrm{~kg} / \mathrm{m} 3$ 


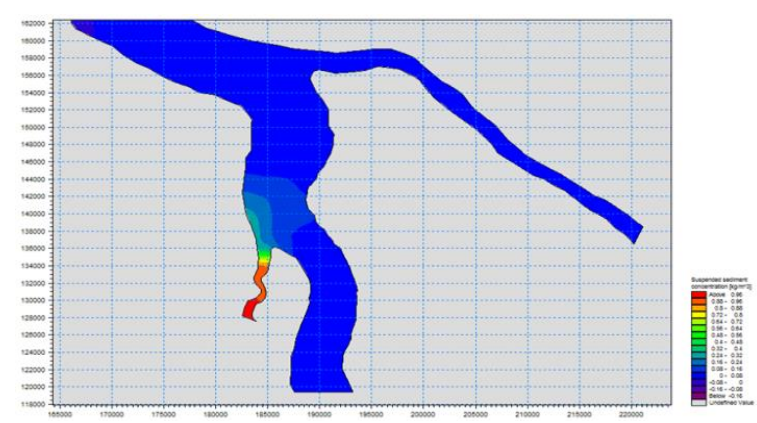

Gambar 12 .sebaran sedimen pada konsentrasi $1 \mathrm{~kg} / \mathrm{m} 3$

Dari gambar di atas dapat dilihat pengaruh input konsentrasi sedimen terhadap sebaran konsentrasi sedimen yang terjadi. Dari titik pengamatan dapat diketahui dengan jelas grafik dari konsentrasi dimasing-masing titik pengamatan selama simulasi berlangsung. Pada Grafik 2 sampai dengan Grafik 4, terlihat peningkatan nilai konsentrasi pada masing titik pengamatan sesuai dengan meningkatnya inputan sedimen. Dengan demikian dapat disimpulkan bahwa tingkat konsentrasi sedimen yang terjadi di muara dalam rentang waktu yang sama sangat dipengaruhi oleh konsentrasi sedimen yang terjadi di hulu sungai.

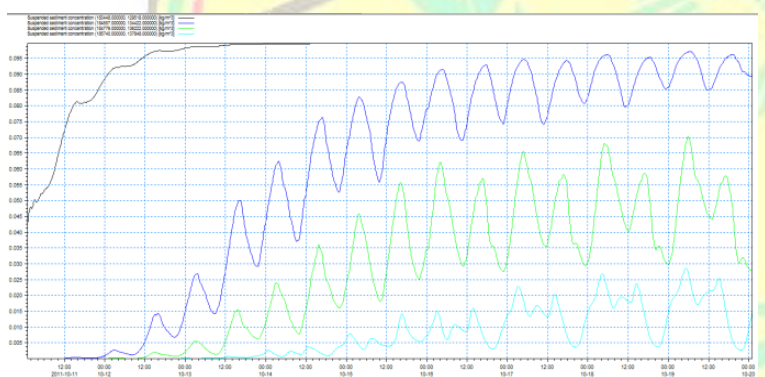

Grafik 2. Konsentrasi pada titik-titik pengamatan dengan konsentrasi input 0,1 $\mathrm{kg} / \mathrm{m} 3$

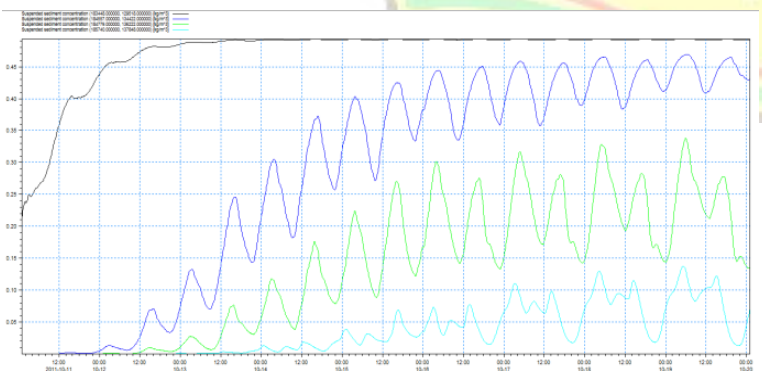

Grafik 3. Konsentrasi pada titik-titik pengamatan dengan konsentrasi input 0,5 $\mathrm{kg} / \mathrm{m3}$

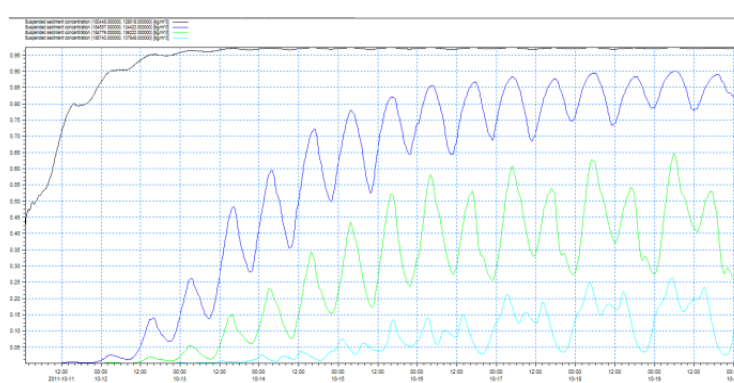

Grafik 4. Konsentrasi pada titik-titik pengamatan dengan konsentrasi input 1 $\mathrm{kg} / \mathrm{m} 3$

\section{Laju Perubahan Elevasi Dasar}

Sedimen suspensi selama dalam perjalanan dari boundary hulu (lokasi input konsentrasi ) akan menglami pengendapan yang dipengaruhi oleh kecepatan aliran dan karakter fisik material sedimen itu sendiri. Proses pengendapan tersebut akan membuat perubahan elevasi dasar sungai dari waktu ke waktu. Dari hasil simulasi dapat diketahui laju perubahan elevasi dasar pada tiaptiap titik yang ditinjau. Laju atau kecepatan perubahan dasar yang terjadi adalah kemiringan rerata dari grafik hubungan perubahan elevasi dasar terhadap waktu. Perubahan elevasi dasar sungai setelah 240 jam disajikan pada Grafik 5 sampai Grafik 7.

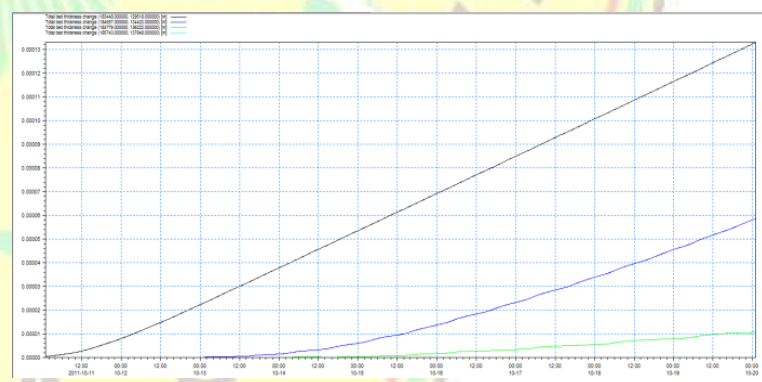

Grafik 5. Perubahan elevasi dasar di titik-titik pengamatan dengan input $0,1 \mathrm{~kg} / \mathrm{m} 3$

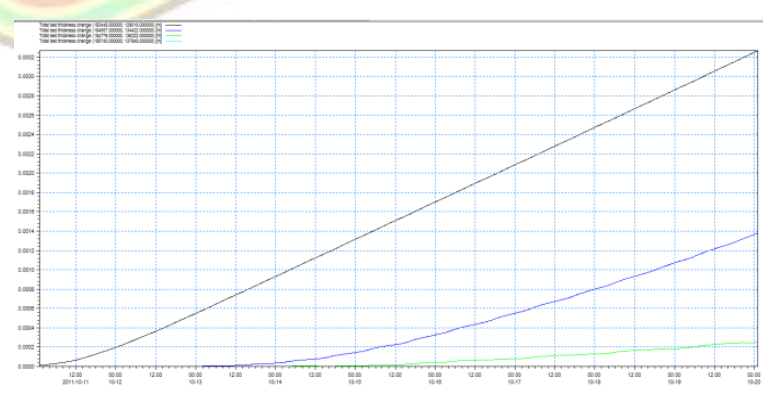

Grafik 6. Perubahan elevasi dasar di titik-titik pengamatan dengan input $0,5 \mathrm{~kg} / \mathrm{m} 3$ 


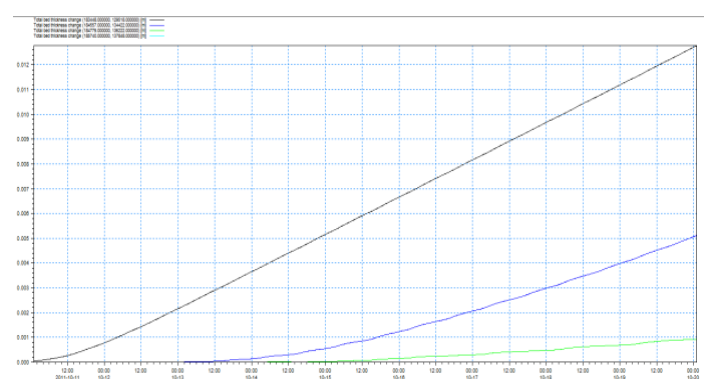

Grafik 7. Perubahan elevasi dasar di titik-titik pengamatan dengan input $1 \mathrm{~kg} / \mathrm{m} 3$

Laju perubahan elevasi dasar pada masingmasing lokasi pengamatan disajikan pada tabel berikut ini:

Tabel 2. Laju perubahan elevasi dasar

\begin{tabular}{|l|l|l|c|c|c|}
\hline \multirow{2}{*}{ Lokasi } & \multirow{2}{*}{$\begin{array}{c}\mathbf{X} \\
(\mathbf{m})\end{array}$} & \multirow{2}{*}{$\begin{array}{c}\mathbf{Y} \\
(\mathbf{m})\end{array}$} & \multicolumn{3}{|c|}{$\begin{array}{c}\text { Laju perubahan } \\
\text { elevasi } \\
\text { (cm/tahun) }\end{array}$} \\
\cline { 4 - 7 } & & & $\mathrm{A}$ & $\mathrm{B}$ & $\mathrm{C}$ \\
\hline $\mathrm{T} 1$ & 183448 & 129518 & 0.32 & 0.468 & 11.52 \\
\hline $\mathrm{T} 2$ & 184557 & 134422 & 0.14 & 0.216 & 5.04 \\
\hline $\mathrm{T} 3$ & 184779 & 136222 & 0.025 & 0.036 & 0.9 \\
\hline $\mathrm{T} 4$ & 185740 & 137848 & 0 & 0 & 0 \\
\hline
\end{tabular}

Keterangan

A. Konsentrasi sedimen $0,1 \mathrm{~kg} / \mathrm{m}^{3}$

B. Konsentrasi sedimen $0,5 \mathrm{~kg} / \mathrm{m}^{3}$

C. Konsentrasi sedimen $1 \mathrm{~kg} / \mathrm{m}^{3}$

Berdasarkan table di atas, laju perubahan elevasi dasar naik $0,1 \mathrm{~cm} /$ tahun dari konsentrasi $0,1 \mathrm{~kg} / \mathrm{m} 3$ ke $0,5 \mathrm{~kg} / \mathrm{m}^{3}$, sedangkan dari konsentrasi $0,5 \mathrm{~kg} / \mathrm{m}^{3} \mathrm{ke} 1 \mathrm{~kg} / \mathrm{m}^{3}$ meningkat sekitar 30 kali dari $0.468 \mathrm{~cm} /$ tahunmenjadi 11.52 $\mathrm{cm} /$ tahun. Pada titik pengamatan ke-4 di daerah ujung muara atau di selat tidak mengalami perubahan elevasi dasar karena konsentrasi sedimen yang terdifusi secara merata ke segala penjuru.

Hasil analisis di atas menggambarkan bahwa masukan sedimen akibat erosi didaratan dari konsentrasi $0,5 \mathrm{~kg} / \mathrm{m}^{3} \mathrm{ke} 1 \mathrm{~kg} / \mathrm{m}^{3}$ meningkat 30 kali

\section{KESIMPULAN DAN SARAN \\ Kesimpulan}

Dari hasil kajian sebaran sedimen dengan metode elemen hingga 2 dimensi dengan studi kasus muara Sungai Siak diperoleh beberapa kesimpulan sebagai berikut: a. Hasil pola arus yang terjadi saat pasang dan saat surut akan memberikan pola sebaran sedimen suspense. Pada saat pasang sebaran sedimen suspense akan mengarah atau cenderung menyebar ke arah selatan, sedangkan pada saat surut sebaran suspensi akan mengarah kea rah utara.

b. Laju perubahan elevesai dasar pada lokasi sungai, muara dan lautmemperlihatkan semakin jauh dari sungai, maka perubahan elevasi dsar perairan semakin rendah.

\section{Saran}

Dari hasil kajian sebaran sedimen dengan metode elemen hingga 2 dimensi dengan studi kasus muara Sungai Siak disarankan agar:

a. Dilakukan kajian lanjutan dengan menggunakan metode elemen 3 dimensi

b. Pengkajian tidak hanya pada partikel sedimen tersuspensi saja namun juga untuk parameter kimia air lainnya, sehingga dapat diperoleh sebaran kualitas perairan secra lengkap.

\section{DAFTAR PUSTAKA}

Dyer, K. R., 1997. Estuaries A Physical Introduction. Jhon Wiley \& Sons Ltd. London. $195 \mathrm{p}$.

Hutabarat, S. dan S. M. Evans, 1986. Pengantar Oseanografi. UI Press. Jakarta. 159 hal.

Effendi, H. 2007. Telaah Kualias Air bagi Pengelolaan Sumber Daya dan Lingkungan Perairan. Kanisius. Jakarta.

Effendi, H. 2003. Telaahan Kualitas Air: Bagi Pengelolaan Sumberdaya dan Lingkungan Perairan. Kanisius. Yogyakarta.

Nybakken, J. W. 1992. Biologi Laut, Suatu Penekatan Ekologis. PT Gramedia. Jakarta.

Dahuri, R., J. Rais, S.P.Ginting, M.J. Sitepu. 2004. Pengelolaan Sumber Daya Wilayah Pesisir dan Lautan Secara Terpadu. Pradnya Paramita. Jakarta.

Davis, A., R. Albert. 1992. Depositional System. An Introduction to Sedimentology and Stratigraphy. Prentice-Hall Inc. New Jersey.

Fifield JS, 2001. Designing for Effective Sediment and Erosion Control on Construction Sites 
US Army, 2003, Users Guide to RMA2 WES Version 4.5, Engineer Research and Development Center Waterways Experiment Station Coastal and Hydraulics Laboratory.

US Army, 2003, Users Guide to SED2D WES Version 4.5, Engineer Research and
Development Center Waterways Experiment Station Coastal and Hydraulics Laboratory. Center, W.L. and J.H. Hill. 1977.Handbook of Variables for Environmental Impact Assessment. Ann. Arbor Science Publisher

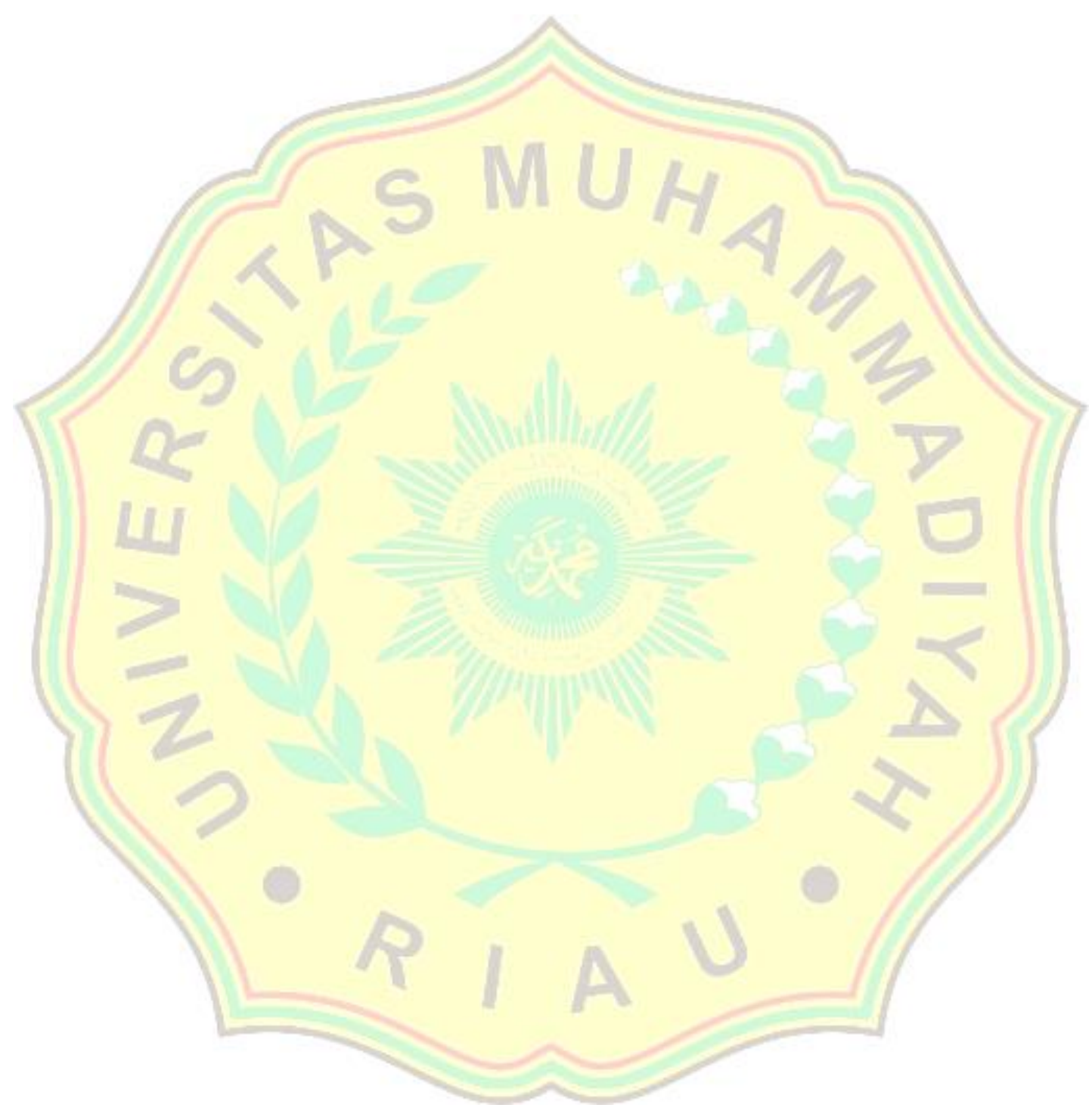

